九州大学学術情報リポジトリ

Kyushu University Institutional Repository

\title{
Comparative Organogenesis between Terrestrial and Epiphytic Cymbidium Species
}

Shimasaki, Kazuhiko

Laboratory of Horticultural science, Faculty of Agriculture, Kyushu University

uemoto, Shunpei

Laboratory of Horticultural science, Faculty of Agriculture, Kyushu University

https://doi.org/10.5109/23865

出版情報: 九州大学大学院農学研究院紀要. 32 (1/2)，pp.31-39，1987-12. Kyushu University バージョン：

権利関係 : 


\title{
Comparative Organogenesis between Terrestrial and Epiphytic Cymbidium Species
}

\author{
Kazuhiko Shimasaki and Shunpei Uemoto \\ Laboratory of Horticultural science, Faculty of Agriculture, \\ Kyushu University 46-01, Fukuoka 812 \\ (Received May 6, 1987)
}

\begin{abstract}
In the terrestrial cymbidium species (C.kanran Makino and C. georingii Reichenbach fil.), rhizome development was induced in axillary buds of pseudobulb by the treatment of auxins. The rate of rhizome induction in the pseudobulbs was enhanced by the application of higher concentrations of NAA and 2,4-D. The application of auxins as lanolin paste was efficient for the rhizome induction.

However, in the epiphytic type (C. dayanum Reichenbach fil. var. austro-japonicum Tuyama), auxin had no effect on rhizome induction from pseudobulb, but, shoot formation was directly induced in the form of axillary bud of pseudobulb by both auxin and cytokinin treatments.
\end{abstract}

\section{INTRODUCTION}

Significant diversity of ecological and morphological types are observed between tropical and temperate cymbidiums. Epiphytic types are typical in the tropical regions, and scarcely forms a rhizome system. On the other hand, the terrestrial types generally distribute in the temperate regions, and rhizome formation is frequently observed as a dormant organ.

In the tropical group, seed germinates readily and develops protocorms on the sterilized culture medium (Knudson, 1922, 1946), and their shoot formation can be seen soon after the protocorm formation. However, in the temperate group, both seed germination and shoot formation are rather difficult comparing with tropical group. After seed germination, rhizome development occurs in the apical meristem of protocorm. Shoot formation from the rhizome would be difficult without addition of auxin and cytokinin (Ueda and Torikata, 1968, 1969-a, 1969-b, Kokubu et. al, 1980). The method for rapid propagation in vitro in the tropical group was developed by $\mathrm{G}$. M. Morel (1960). He noted that protocorm-like body (PLB), from which young seedlings were formed, were developed around the shoot tip cultures. Since this first study, morphological study in vitro (Wimber, 1963, Morel, 1964, Matsui et. al, 1964, Sagawa and Shoji, 1966, Vacherot, 1966, Wirfret, 1966, Bivins and Hacket, 1969, Steword and Mapes, 1971, Thompson, 1971, Wirckmeister, 1971, Kusumoto, 1980) has rapidly progressed.

However, in the terrestrial types, instead of PLB formation, rhizome development is observed in the meristem tissue culture in vitro. Difficulty in plantlet formation from the rhizome culture is similar to the seedling formation.

In this study, the effects of the chemicals on the morphological developments in vivo in terrestrial and epiphytic Cymbidium species are examined. 


\section{MATERIALS AND METHODS}

\section{Application of auxins and cytokinin as lanolin pastes}

a) Mature plants of C. kanran Makino without rhizome were collected in Kochi Prefecture, Japan. After detaching of each pseudobulb having leaves and roots, auxins such as $\alpha$-naphthylacetic acid (NAA), indole-3-butyric acid (IBA) and cytokinin, $\mathrm{N}^{6}{ }_{-}$ benzylaminopurine (BA) were applied separately at concentrations of $0.1,1,10,50$ or $100 \mathrm{ppm}$, respectively. These agents were dissolved at first in small volume of $95 \%$ ethanol and then dissolved in distilled water, and added to the lanolin paste. Lanolin paste with ethanol and distilled water was used as the control. These treatments were conducted on April 23, 1983. All plants were grown in a green house at Kyushu Univ., and the results were estimated on September 22, 1983.

b) Mature plants of C. georingii Reichenbach fil. Without rhizome were collected in Fukuoka Prefecture, Japan. After detaching each pseudobulb having leaves and roots, NAA, IBA, 2,4-dichlorophenoxyacetic acid (2,4-D) or BA were applied in the same manner stated above.

\section{Application of auxins and cytokinin as aqueous solution}

Mature plants of C. goeringi Reichenbach fil. and C. dayanum Reichenbach fil. var. austra-japonicum Tuyama were grown in a green house at Kyushu Univ.. After shoots and roots were excised, pseudobulbs were detached each other. 2,4-D and BA were applied on pseudobulbs as aqueous solutions singly or in combinations at concentrations of $0,0.1,1,10$ and $100 \mathrm{ppm}$, respectively. These pseudobulbs were soaked in the solutions for 24 hours. The $\mathrm{pH}$ of the solutions were adjusted to 5.5 with $0.1-0.5$ $\mathrm{N} \mathrm{NaOH}$ or $\mathrm{HCl}$. These treatments were conducted on April 19,1986. All plants were grown at $25^{\circ} \mathrm{C}$ under dark condition, and examined on August 2, 1986.

\section{RESULTS}

1-a) Effects of auxins and a cytokinin on organogenesis in axillary buds of C. kanran Makino are summarized in Table 1. Rhizome development as an axillary bud in pseudobulb was observed in all cases except for the case of higher concentrations of BA or IBA. Application of NAA was effective for rhizome development in axillary buds. Additional organogenesis as a shoot was observed in an apex segment of the rhizome by the treatment of lower concentrations of NAA. Higher concentrations of NAA inhibited shoot formation in an apex segment of rhizome. Rhizome elongation was promoted by the application of 10 or $50 \mathrm{ppm}$ NAA (Fig. 1). The number of rhizomes also increased by the application of NAA and the best result was obtained at $1 \mathrm{ppm}$. The shoot development as an axillary bud was enhanced at higher concentrations of $\mathrm{BA}$. $\mathrm{N}^{6}$-benzylaminopurine at concentrations ranging from 1 to $50 \mathrm{ppm}$ are efficient for shoot formation. Application of IBA inhibited both shoot and rhizome development.

1-b) Effects of auxins and a cytokinin on organogenesis in axillary buds of C. georingii Reichenbach fil. are summarized in Table 2. Rhizome development as an axillary bud of $\mathrm{C}$. georingii Reichenbach fil. was induced by the application of higher concentrations of NAA, 2,4-D or IBA. Lanolin paste without chemicals or only BA 


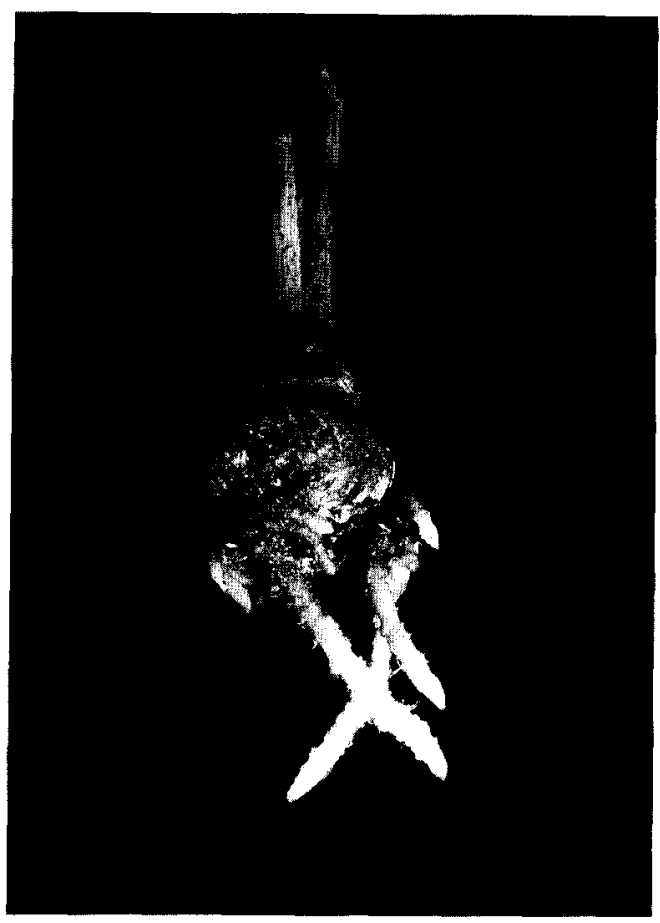

Fig. 1. Rhizome development in pseudobulb axillary buds of C. kanran Makino induced by the application of $50 \mathrm{ppm}$ of NAA.

Table 1. Effects of auxins and cytokinin on organogenesis in pseudobulbs of C. kanran Makino.

\begin{tabular}{|c|c|c|c|c|c|c|c|}
\hline \multirow{2}{*}{\multicolumn{2}{|c|}{ Treatment (ppm) }} & \multicolumn{2}{|c|}{ Number } & \multicolumn{2}{|c|}{ Length (mm) } & \multicolumn{2}{|c|}{ Formation rate $(\%)$} \\
\hline & & Rhizome & Shoot & Rhizome & Shoot & Rhizome & Shoot \\
\hline \multicolumn{2}{|c|}{ Control } & 0.2 & 0.6 & 4.2 & 57.0 & 20 & 60 \\
\hline \multirow[t]{5}{*}{ BA } & 0.1 & 0.5 & 0.4 & 5.8 & 4.8 & 50 & 25 \\
\hline & 1 & 0.5 & 0.5 & 5.4 & 41.9 & 20 & 80 \\
\hline & 10 & 0.2 & 0.8 & 1.8 & 75.2 & 20 & 100 \\
\hline & 50 & 0 & 1.0 & - & 75.2 & 0 & 100 \\
\hline & 100 & 0 & 1.0 & - & 16.1 & 0 & 100 \\
\hline \multirow[t]{5}{*}{ NAA } & 0.1 & 0.3 & 1.0 & 1.3 & 32.8 & 25 & 75 \\
\hline & 1 & 1.3 & 0.8 & 8.1 & 24.0 & 100 & 75 \\
\hline & 10 & 0.8 & 0.8 & 6.8 & 42.1 & 80 & 80 \\
\hline & 50 & 1.0 & 1.0 & 11.2 & 46.2 & 100 & 100 \\
\hline & 100 & 1.0 & 0.5 & 11.9 & 8.6 & 100 & 50 \\
\hline \multirow[t]{5}{*}{ IBA } & 0.1 & 0.2 & 0.8 & 1.1 & 13.9 & 20 & 75 \\
\hline & 1 & 0.5 & 0.8 & 3.6 & 18.6 & 60 & 60 \\
\hline & 10 & 0.3 & 0.8 & 4.1 & 26.8 & 50 & 75 \\
\hline & 50 & 0 & 0.8 & - & 58.1 & 0 & 60 \\
\hline & 100 & 0.2 & 1.0 & 1.3 & 44.4 & 20 & 100 \\
\hline
\end{tabular}


had no effect on the rhizome development. Higher concentrations of NAA or IBA slightly promoted rhizome elongation. 2,4-dichlorophenoxyacetic acid at concentrations ranging from 1 to $50 \mathrm{ppm}$ were efficient for rhizome formation and the best result was obtained at $1 \mathrm{ppm}$. Shoot elongation was inhibited by the treatments of NAA, 2, 4-D and higher concentrations of BA. Lower concentrations of BA was effective for shoot elongation. The number of induced rhizome in axillary buds were increased when 2,4-D at concentrations ranging from 1 to $10 \mathrm{ppm}$ IBA or $50 \mathrm{ppm}$ NAA were applied and the best result was obtained at $1 \mathrm{ppm}$ concentration of 2,4-D. Shoot formation was observed in all plants treated with NAA, IBA, BA, or lanolin paste without chemicals. 2,4-D at concentrations ranging from 1 to $50 \mathrm{ppm}$ inhibited shoot formation.

Table 2. Effects of auxins and cytokinin on organogenesis in pseudobulbs of C. goeringii Reichenbach. fil..

\begin{tabular}{|c|c|c|c|c|c|c|c|}
\hline \multirow{2}{*}{\multicolumn{2}{|c|}{ Treatment (ppm) }} & \multicolumn{2}{|c|}{ Number } & \multicolumn{2}{|c|}{ Length (mm) } & \multicolumn{2}{|c|}{ Formation rate $(\%)$} \\
\hline & & Rhizome & Shoot & Rhizome & Shoot & Rhizome & Shoot \\
\hline \multirow{2}{*}{\multicolumn{2}{|c|}{$\begin{array}{l}\text { Control } \\
\text { BA }\end{array}$}} & 0 & 1.0 & \multirow[t]{2}{*}{ - } & 169.3 & 0 & 100 \\
\hline & 0.1 & 0 & 1.4 & & 182.5 & 0 & 100 \\
\hline & 1 & 0 & 1.5 & \multirow{2}{*}{-} & 153.3 & 0 & 100 \\
\hline & 10 & 0 & 1.2 & & 33.4 & 0 & 100 \\
\hline & 50 & 0 & 1.3 & - & 58.8 & 0 & 100 \\
\hline & 100 & 0 & 1.1 & \multirow[t]{2}{*}{-} & 179.5 & 0 & 100 \\
\hline \multirow[t]{5}{*}{ NAA } & 0.1 & 0 & 1.0 & & 86.4 & 0 & 100 \\
\hline & 1 & 0 & 1.0 & \multirow{2}{*}{-} & 72.7 & 0 & 100 \\
\hline & 10 & 0 & 1.0 & & 79.8 & 0 & 100 \\
\hline & 50 & 0.3 & 1.1 & 2.8 & 51.8 & 28 & 100 \\
\hline & 100 & 0.2 & 1.4 & 1.0 & 67.2 & 14 & 100 \\
\hline \multirow[t]{5}{*}{ IB A } & 0.1 & 0.4 & 1.0 & 4.3 & 67.1 & 14 & 100 \\
\hline & 1 & 0.3 & 1.0 & 2.1 & 72.1 & 14 & 100 \\
\hline & 10 & 0.2 & 1.1 & 1.6 & 96.8 & 20 & 100 \\
\hline & 50 & 0.2 & 1.5 & 1.8 & 99.7 & 22 & 100 \\
\hline & 100 & 0.3 & 1.0 & 1.7 & 56.2 & 25 & 100 \\
\hline \multirow[t]{5}{*}{ 2,4-D } & 0.1 & 0 & 1.4 & - & 86.3 & 0 & 100 \\
\hline & 1 & 0.8 & 1.0 & 9.8 & 18.1 & 50 & 80 \\
\hline & 10 & 1.1 & 0.8 & 6.8 & 27.1 & 100 & 80 \\
\hline & 50 & 0.7 & 0.6 & 6.3 & 42.8 & 71 & 57 \\
\hline & 100 & 0.2 & 1.2 & 1.0 & 58.2 & 17 & 100 \\
\hline
\end{tabular}

2-a) Effects of BA and 2,4-D as aqueous solution on organogenesis in axillary buds of C. georingii Reichenbach fil. are summarized in Table 3. Rhizome development in axillary buds was occurred by the treatment at higher concentrations of 2,4$\mathrm{D}$ with BA and the best result was obtained at $10 \mathrm{ppm} 2,4-\mathrm{D}$ with $0.1 \mathrm{ppm}$ BA. Shoot elongation was promoted when $\mathrm{BA} / 2,4-\mathrm{D}$ ratios were ranged from 1 to 10 . One

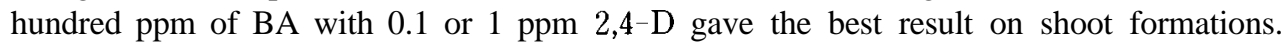

2-b) Effects of BA and 2,4-D on the organogenesis in axillary buds of C. dayanum Reichenbach fil. var. austro-japonicum Tuyama are summarized in Table 4. BA applied singly promoted shoot elongation and gave the best result at $10 \mathrm{ppm}$ of BA. 
Table 3. Effects of BA and 2,4-D on organogenesis in pseudobulbs of C. goeringii Reichen bach. fil..

\begin{tabular}{cccccccc}
\hline \multicolumn{2}{c}{ Treatment $(\mathrm{ppm})$} & \multicolumn{2}{c}{ Number } & Length $(\mathrm{mm})$ & Formation rate (\%) \\
\hline BA & $2,4-\mathrm{D}$ & Rhizome & Shoot & Rhizome & Shoot & Rhizome & Shoot \\
\hline 0 & 0 & 0 & 1.0 & - & 63.2 & 0 & 30 \\
0 & 0.1 & 0 & 1.4 & - & 57.7 & 0 & 70 \\
0 & 1 & 0.6 & 1.0 & 5.4 & 33.4 & 22 & 44 \\
0 & 10 & 0 & 1.0 & - & 30.7 & 0 & 71 \\
0 & 100 & 0 & 0.3 & - & 15.2 & 0 & 33 \\
0.1 & 0 & 0 & 1.2 & - & 28.5 & 0 & 45 \\
0.1 & 0.1 & 0 & 1.2 & - & 76.9 & 0 & 60 \\
0.1 & 1 & 0 & 1.0 & - & 61.2 & 0 & 60 \\
$\mathbf{0} .1$ & 10 & 0.7 & 0.8 & 13.8 & 44.3 & 25 & 36 \\
$\mathbf{0 . 1}$ & 100 & 0.4 & 1.0 & 3.8 & 8.6 & 22 & 44 \\
1 & 0 & 0 & 1.3 & - & 19.0 & 0 & 67 \\
1 & 0.1 & 0 & 1.0 & - & 67.7 & 0 & 60 \\
1 & 1 & 0 & 1.0 & - & 58.2 & 0 & 40 \\
1 & 10 & 0 & 1.2 & - & 26.3 & 0 & 71 \\
1 & 100 & 0.5 & 1.0 & 2.5 & 5.1 & 33 & 33 \\
10 & 0 & 0 & 1.2 & - & 29.5 & 0 & 69 \\
10 & 0.1 & 0 & 1.4 & - & 45.2 & 0 & 50 \\
10 & 1 & 0 & 1.0 & - & 46.5 & 0 & 40 \\
10 & 10 & 0 & 0.3 & - & 50.0 & 0 & 10 \\
10 & 100 & 0 & 1.0 & - & 9.0 & 0 & 43 \\
100 & 0 & 0 & 1.7 & - & 35.0 & 0 & 38 \\
100 & 0.1 & 0 & 2.6 & - & 30.2 & 0 & 70 \\
100 & 1 & 0 & 2.7 & - & 27.1 & 0 & 33 \\
100 & 10 & 0 & 1.0 & - & 53.5 & 0 & 10 \\
100 & 100 & 3.0 & 1.0 & 3.0 & 5.7 & 13 & 50 \\
\hline
\end{tabular}

However, addition of 2,4-D resulted in an inhibition of shoot elongation. Rhizome development in the axillary buds in each plant did not occur. Both BA and 2,4-D had no effect on the number of shoot developed in pseudobulbs. The application of 10 or $100 \mathrm{ppm}$ of 2,4-D resulted in the death of all plants.

\section{DISCUSSION}

Cymbidium kanran Makino and C. georingii Reichenbach fil. are the representative terrestrial species in the temperate regions, Japan. Cymbidium dayanum fil. is an epiphytic type distributing both in the tropical and temperate regions. Significant differentiations in the morphological growth responses by chemicals were observed between these two types. These differenciations supposed to attributed in the differences in growth cycles, i. e., the epiphytic Cymbidium species (Table 5 and 6) develop shoots immediately after the protocorm formation. However, the terrestrial types (Table 6) develop rhizome as a dormant organ soon after the protocorm formation. The rhizome continues to grow and branch out under the ground for comparatively long durations. Therefore, shoot formation cannot be observed. In temperate zone plant, rhizome is formed as a sort of dormant organ. Therefore, in the terrestrial type species of Cymbidium, shoot formations observed after their dormancy would be 
Table 4. Effects of BA and 2,4-D on organogenesis on shoot formation of C. dayanum Reichenbach fil. var. austro-iaponicum Tuyama.

\begin{tabular}{|c|c|c|c|c|}
\hline \multicolumn{2}{|c|}{ Treatment (ppm) } & \multirow{2}{*}{ Number } & \multirow{2}{*}{ Length (mm) } & \multirow{2}{*}{$\begin{array}{l}\text { Formation } \\
\text { rate }(\%)\end{array}$} \\
\hline $\mathrm{BA}$ & $2,4-\mathrm{D}$ & & & \\
\hline 0 & 0 & 0.3 & 33.0 & 28 \\
\hline 0 & 0.1 & 0.7 & 15.1 & 50 \\
\hline 0 & 1 & 0.2 & 22.4 & 20 \\
\hline 0 & 10 & 0.2 & 3.9 & 20 \\
\hline 0 & 100 & 0.2 & 2.6 & 20 \\
\hline 0.1 & 0 & 1.0 & 50.0 & 71 \\
\hline 0.1 & 0.1 & 0.4 & 14.7 & 43 \\
\hline 0.1 & 1 & 0.3 & 25.6 & 30 \\
\hline 0.1 & 10 & 0.2 & 9.7 & 20 \\
\hline 0.1 & 100 & 0 & - & 0 \\
\hline 1 & 0 & 0.5 & 70.0 & 50 \\
\hline 1 & 0.1 & 0.3 & 28.7 & 33 \\
\hline 1 & 1 & 0.7 & 5.6 & 43 \\
\hline 1 & 10 & 0.3 & 13.8 & 15 \\
\hline 1 & 100 & 0 & - & 0 \\
\hline 10 & 0 & 0.6 & 73.6 & 57 \\
\hline 10 & 0.1 & 0.1 & 45.0 & 14 \\
\hline 10 & 1 & 0.3 & 13.7 & 33 \\
\hline 10 & 10 & 0.1 & 2.5 & 14 \\
\hline 10 & 100 & 0 & - & 0 \\
\hline 100 & 0 & 0.5 & 50.4 & 50 \\
\hline 100 & 0.1 & 0.2 & 20.3 & 16 \\
\hline 100 & 1 & 0.7 & 17.6 & 67 \\
\hline 100 & 10 & 0 & - & 0 \\
\hline 100 & 100 & 0 & & 0 \\
\hline
\end{tabular}

finished. Dormant growth stage in the form of rhizome is supposed to be obtained during expansion or movement of geographical distribution. By a terrestrial growth habit, they could show an expansion of distribution under various environments. Cymbidium kanran Makino have achieved movement and expansion of distribution from southern area of the peoples' Republic of China through Shizuoka Prefecture in Japan. As for C. georingii Reichenbach fil. have achieved movement and expansion of geographical distribution from southern area in the peoples' Republic of China to Hokkaido in Japan. Similar ecological and morphological differences can be observed in the case of bamboo (Uchimura, 1978), i.e., bamboo species like Bambusa, Dendrocalamus and Schizostachyum genera which grow in the tropical region, clump of culms is observed, i. e., shoot formation directly occures at the lower portion of culms. On the other hand, non clump-forming type represented by the genera Phyllostachys, Semiarundinaria and Melocanna, are distributed in the temperate and higher latitude region, extend rhizome under the ground after seed germination.

In the terrestrial Cymbidium species, the protocorm stage is supposed to play a role as predormant growth stage. This stage is observed both tropical and temperate cymbidiums on sterized culture media. This fact suggested that protocorm is a originate growth stage in these species. Protocorm as a predormant growth stage is supposed to be induced by instability in a premature embryo of seed. Similar aspects 
were seen in the meristem culture of the shoots. This response was also supposedly caused by instability in the meristem tissue. The results in these experiments suggested that auxin play an important role to the induction of development of the dormant organ in the form of rhizome in mature plants. By the application of higher concentrations of auxin, rhizome continue to elongate and branch out because of the dormancy in the plant. By the application of lower concentrations of auxin, shoot formation was observed in the apical segment of rhizome. This fact suggested that dormancy in the plant was broken immediately after rhizome formation. On the other hand, higher concentrations of cytokinin inhibited the induction of dormancy. In the tropical types, 2,4-D inhibited shoot elongation. These results suggested the dormant growth stage in the form of rhizome have not been obtained for these species. For these reasons, the tropical epiphytic types are supposed to have difficulty in the movement and expantion of distribution to the temperate regions. The tropical epiphytic types are supposed to have difficulty in the movement and expansion of distribution to the temperate region.

Table 5. Representative epiphytic Cymbidium species and their distributions

\begin{tabular}{ll}
\hline \multicolumn{1}{c}{ Species } & \multicolumn{1}{c}{ Distributions } \\
\hline C. aloifolium Sw. & Philippines, Burma, Srilanka \\
C. dayanum Reichb. fil. & Japan, China, Taiwan, Indonesia, Malaysia \\
C. devonianum Paxt. & India, Himalaya, \\
C. erythraecum Lindl. & China, India, Bhutan, Nepal, Burma \\
C. finlaysonianum Lindl. & Philippines, Indonesia, Burma, Vietnam \\
C. floribundum Lindl. & China, Taiwan \\
C. giganteum Wall & India, Himalaya \\
C. grandiflonum Griff. & India, Bhutan \\
C. hookerianum Reichb. fil. & China, India, Bhutan, Nepal \\
C. i'ansonii Lindl. & Burma \\
C. iridioides D. Don & China, India, Bhutan \\
C. javanicum Bl. & China, Taiwan, \\
C. lancifolium Hook. & Tropical region of Asia \\
C. longifolium D. Don & China, Nepal, India, Burma \\
C. parishii Reichb. fil. & Burma \\
C. pendulum Sw. & China, India, Burma, Vietnam, \\
C. pumilum Rolfe & China \\
C. simulans Rolfe & China, India, Burma, Vietnam, Thailand \\
\hline
\end{tabular}

Table 6. Representative semi-epiphytic Cymbidium species and their distributions.

\begin{tabular}{ll}
\multicolumn{1}{c}{ Species } & Distributions \\
\hline C. canaliculatum R. Br. & Australia \\
C. eburneum Lindl. & Himalaya, Burma \\
C. erythrostylum Rolfe & Vietnam \\
C. insigne Rolfe & China, Bietnum \\
C. Iowianum Reichb. fil. & Burma \\
C. masterii Par. & India, Himalaya \\
C. tigrinum Par. & Burma \\
C. tracyanum Rolfe & Burma \\
\hline
\end{tabular}


Table '7. Representative terrestrial Cymbidium species and their distributions.

\begin{tabular}{|c|c|}
\hline Species & Distributions \\
\hline $\begin{array}{l}\text { C. aberrans Schltr. } \\
\text { C. allo-marginatum Makino } \\
\text { C. ensifolium Sw. } \\
\text { C. faberi Rolfe } \\
\text { C. formosanum Hay. et Fukuyama } \\
\text { C. forrestii Rolfe } \\
\text { C. goeringii Reichb. fil. } \\
\text { C. gracillimum Fukuyama } \\
\text { C. gyokuchin Makino } \\
\text { C. javanicum Blume } \\
\text { C. kanran Makino } \\
\text { C. koran Makino } \\
\text { C. Iancifolium Hook. } \\
\text { C. linearisepalum Yamamoto } \\
\text { C. macrorhizum Lindl. } \\
\text { C. misericors Hay. } \\
\text { C. nipponicum Makino } \\
\text { C. niveo-marginatum Makino } \\
\text { C. oiwakensis Hay } \\
\text { C. purpureo-hiemale Hay. } \\
\text { C. mbrigemmum Hay. } \\
\text { C. sinense Willd } \\
\text { C. yakibaran Makino } \\
\text { C. yakusimense Masamune }\end{array}$ & $\begin{array}{l}\text { Japan } \\
\text { China } \\
\text { China } \\
\text { China, Taiwan } \\
\text { Taiwan } \\
\text { China } \\
\text { Japan } \\
\text { Taiwan } \\
\text { China, Taiwan } \\
\text { Japan, Taiwan, Malaysia, Himalaya } \\
\text { Japan, China, Taiwan } \\
\text { Japan } \\
\text { Japan, Taiwan, India } \\
\text { Taiwan } \\
\text { China, India } \\
\text { Taiwan } \\
\text { Japan } \\
\text { China } \\
\text { Taiwan } \\
\text { Taiwan } \\
\text { Taiwan } \\
\text { China, Taiwan } \\
\text { China, Japan } \\
\text { Japan }\end{array}$ \\
\hline
\end{tabular}

\section{ACKNOWLEDGEMENT}

The authers wish to dedicate this paper to the Associate Professor T. Kawarabata, Institute of Biological Control, Faculty of Agriculture, Kyushu Univ. for his providing samples.

\section{REFERENCES}

Bivins, J. L. and W. P. Hackett 1969 The effect of medium and wounding techniques on aseptic culture of Cymbidium orchid from shoot apices. Plant Propagator, 15: 9914

Knudson, L. 1922 Non-symbiotic germination of orchid seeds. Bot. Gat., 73 : 1-25

Knudson, L. 1946 A new nutrient for the germination of orchid seeds. Amer. O rchid Soc. Bull., 36 : $125-126$

Kokubu, T., Y. Kaieda, Y. Higashi, T. Kitano and K. Fukamizu 1980 Organogenesis in sterile culture of oriental Cymbidium, Cymbidium kanran Makino. Mem. Fac. Agr. Kagoshima Univ., 16: $53-64$

Kusumoto, M. 1980 Interform of the proliferation, organogenesis and effects of growth regurating substances on Cymbidium protocorms cultured in vitro. J. Japan. Soc. Hort. Sci., 48 : 510-518

Matsui, T., K. Kawai and Y. Samata 1970 Effect of $\mathrm{N}^{6}$-benzylaminopurine and $\alpha$-naphthaleneacetic acid on the organogenesis of Cymbidium Fac.Agri. Bull., Tamagawa Univ., 10 : 99 $-106$

Morel, G. 1960 Producing virus free cymbidiums. Amer. O rchid Soc. Bull., 29 : 495-497

Morel, G. 1964 Tissue culture, a new means of clonal propagation of orchids. Amer. O rchid Soc. 
Bull., $29: 495-497$

Sagawa, Y. and T. Shoji 1966 Clonal propagation of cymbidiums through shoot meristem culture. Amer. Orchid Soc. Bull., 35: 118-122

Steword, F. C. and M. 0. Mapes 1971 Morphogenesis in aseptic cell cultures of Cymbidium. Bot. Gaz., 132: 65-70

Thompson, R. P. 1971 Excision of Cymbidium meristem. Amer. Orchid Soc. Bull., 40: 580-584

Ueda, H. and H. Torikata 1968 Organogenesis in meristem cultures of Cymbidiums I. Studies on the effect of growth substances added to the culture media under continuous ilumination. $J$. Japan. Soc. Hort. Sci., 37: 240-248

Ueda, H. and H. Torikata 1969-a Organogenesis in the meristem tissue cultures of cymbidiums. II. Effect of growth substances on the organogenesis in dark culture. J. Japan. Soc.Hort. Sci., 38 : 188-193

Ueda, H. and H. Torikata 1969-b Organogenesis in the meristem cultures of cymbidiums. III. Historical studies on the shoot formation at the rhizome-tips of Cymbidium georingii Reichb. $\mathrm{f}$. cultured in vitro. J. Japan. Soc. Hort. Sci., 38: 262-266

Uchimura, E. 1978 Ecological studies on cultivation of tropical bamboo forest in the Philippines. Bull. For. and For. Prod. Inst., 301: 79-118

Vacherot, M. 1966 Meristem tissue culture propagation of orchids. Proc. 5th World Orchid Conf.. Long Beach, pp. 23-26

Werckmeister, P. 1971 Light induction of geotropism and the control of proliferation and growth of Cymbidium. Bot. Gaz., 132: 346-350

Wilfret, G. J. 1966 Formation of protocorm-like bodies on excised Cymbidium shoot tips. Amer. Orchid Soc. Bull., 35: 823-827

Wimber, D. E. 1963 Clonal multiplication of cymbidiums through culture of the shoot meristem. Amer. Orchid Soc. Bull., 32: 105-107 